\title{
A TECHNIQUE OF ANAESTHESIA FOR CANCER PERFUSION
}

\author{
S. H. Stolar, M.D., and J. E. Wynands, M.D.
}

IN RECENT YEARS techniques have been developed which permit specific treatment of patients with inoperable cancer. These techniques involve the perfusion of cancerous areas with cytotoxic agents. To derive maximum therapeutic effect from these drugs, the temperature of the area involved must be controlled. Bergel ${ }^{1}$ states that the activity of nitrogen mustard increases by a factor of two for each $10^{\circ}$ C. rise in temperature. Rochlin" using P3:-labelled T.E.P.A. found a direct relationship between the temperature and the uptake of the dnig. Shingleton ${ }^{3}$ has shown that hyperthermia increases the uptake of ritrogen mustard, while hypothermia depresses the uptake $e^{4}$ and offers protection to the bone marrow. ${ }^{5}$

On the basis of these reports, the Department of Surgery in our hospital decided to isolàte and perfuse the affected areas in cancer patients with cytotoxic agents and blood heated to $40^{\circ} \mathrm{C}$. The anaesthetic technique for these patients included general body hypothermia with the intention of protecting normal tissues from the toxic action of any drug which might escape from the perfusion system.

\section{Techrique}

Premedication is with pentobarbital, meperidine, and atropine as for any operative procedure. A continuous epidural anaesthetic using 2 per cent Lidocaine with adrenaline $1: 200,000$ is instituted and a $T_{4}$ level achieved. Dosage is calculated according to the method of Bromage ${ }^{6}$ General anaesthesia is induced with thiopentone and maintained by endotracheal nitrous oxide, halothane, and oxygen. The patient is cooled to $30^{\circ}$ C. The E.C.G., oesophageal temperature, blood pressure, and pulse are carefully monitored, and respiration is controlled throughout the procedure.

In carrying out this technique certain points bear elaboration. Epidural anaesthesia with its peripheral vasodilating action facilitates heat transfer and thus decreases cooling time.

Galindo $^{7}$ has stated that deep general anaesthesia protects the heart against ventricular fibrillation but the resultant myocardial depression reduces cardiac output and makes defibrillation difficult should it be necessary. The basis for the protection provided by deep anaesthesia is presumably due to reduction of circulating endogenous catecholamines and direct depression of cardiac muscle. Epidural anaesthesia affords this protection without producing myocardial depression.

A depth of nitrous oxide/halothane anaesthessia sufficient only to keep the patient asleep and tolerating an endotracheal tube is employed. The patient is intubated in order that he may be hyperventilated.

${ }^{\circ}$ Royal Victoria Hospital, Montreal. 
Goldberg et al. ${ }^{8}$ and Rall et al. ${ }^{9}$ have shown that acidotic central nervous system tissues have a greater affinity for drugs than the same tissues in an alkalotic state. We have thus hyperventilated our patients in the hope of reducing tissue uptake of any systemically circulating cytotoxic drugs.

On the basis of arterial blood studies during open-heart surgery, we have found that by hyperventilating the patient at approximately twice the normal minute volume predicted by the Radford nomogram, ${ }^{10}$ the $\mathrm{pCO}_{2}$ has been reduced to the neighbourhood of $30 \mathrm{~mm}$. Hg. This has resulted in a respiratory alkalosis, the $\mathrm{pH}$ being in the range of 7.5 to 7.7 .

The $\mathrm{pH}$ of a perfusate is acidotic in the range of 7.20 to 7.25 because of a high $\mathrm{pCO}_{2}$. This $\mathrm{pH}$ is rapidly brought to normal levels by the action of the
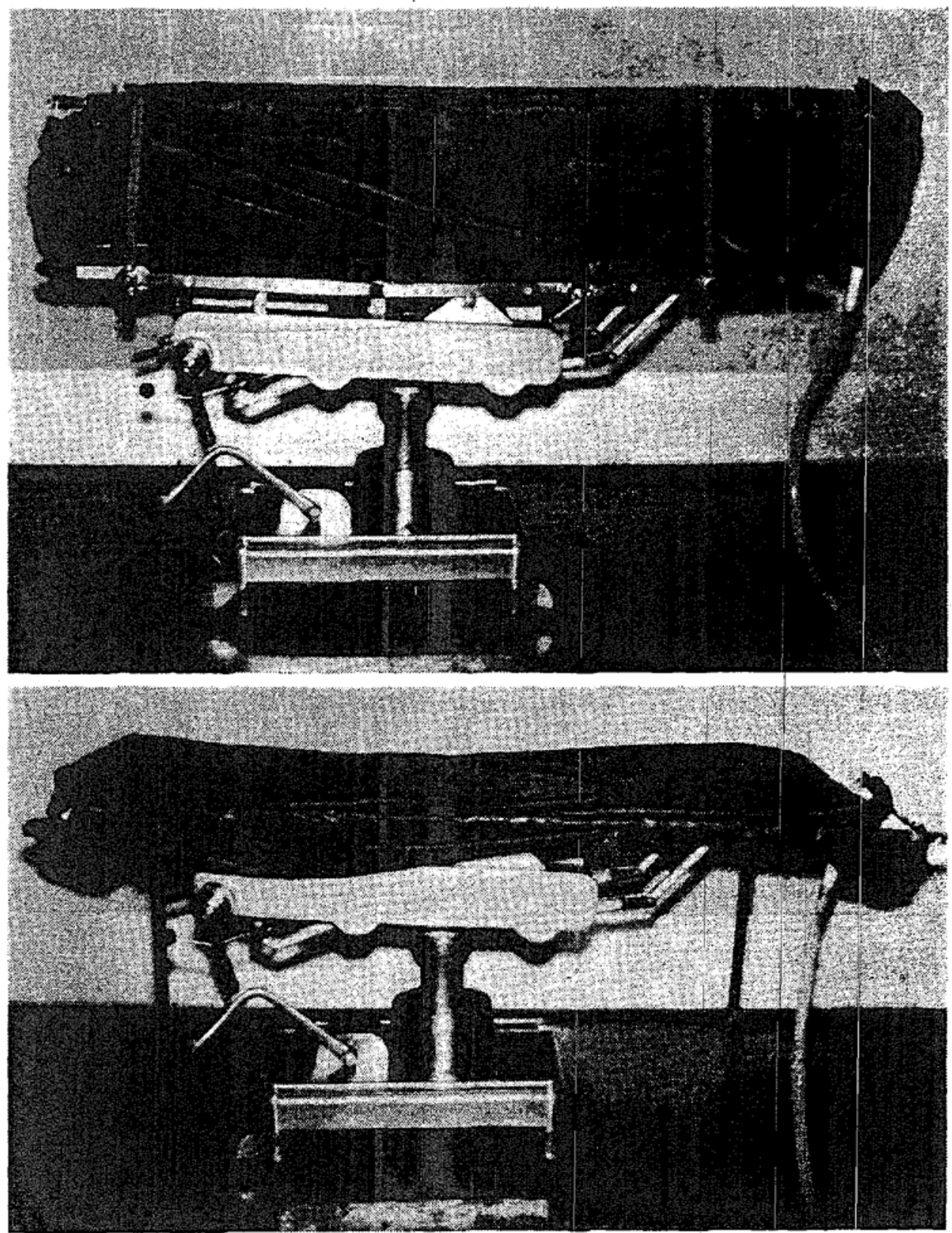

Figune 1. Top: tub erect. Bottom: tub collapsed. 
heart-lung machine. Ultimately there exists a $\mathrm{pH}$ gradient between the patient and the perfusion system of 0.2 unit with the perfusate being the more acidotic. Presumably the addition of $\mathrm{CO}_{2}$ to the heart-lung machine would further enhance this $\mathrm{pH}$ gradient.

Cooling of the patient has been accomplished by means of a collapsible rubber tub as shown in Figures 1 and 2.

The advantages of the tub employed for this technique are: (1) it is inexpensive; (2) it is easily constructed; (3) it is strong and easily cleansed; (4) it is electrically conductive; (5) it is easily filled and drained; (6) it does not require the transfer of the patient; and (7) it does not interfere with surgery.

The tub is placed on the operating table in the collapsed position and the patient is anaesthetized. Two Rochester plastic catheters ${ }^{11}$ are inserted, one in each arm, and after spraying with tincture of benzoin they are affixed with plastic waterproofed tape. The epidural catheter is protected in a similar fashion. Standard lead 1 of the E.C.G. is employed, and the arms are folded over the chest out of the water. When the patient has been anaesthetized the sides of the tub are erected, and the tub filled with cold tap water until only the head and arms remain uncovered. To prevent warming, water is continuously circulated through the tub. The patient remains immersed in the cold water until his oesophageal temperature reaches $32^{\circ}$ to $33^{\circ} \mathrm{C}$. The water is then drained, the sides are lowered, the patient is dried, and the operation is commenced. By the time the preparations have been made for perfusion, the temperature will have drifted to $30^{\circ} \mathrm{C}$. plus or minus $1^{\circ}$.
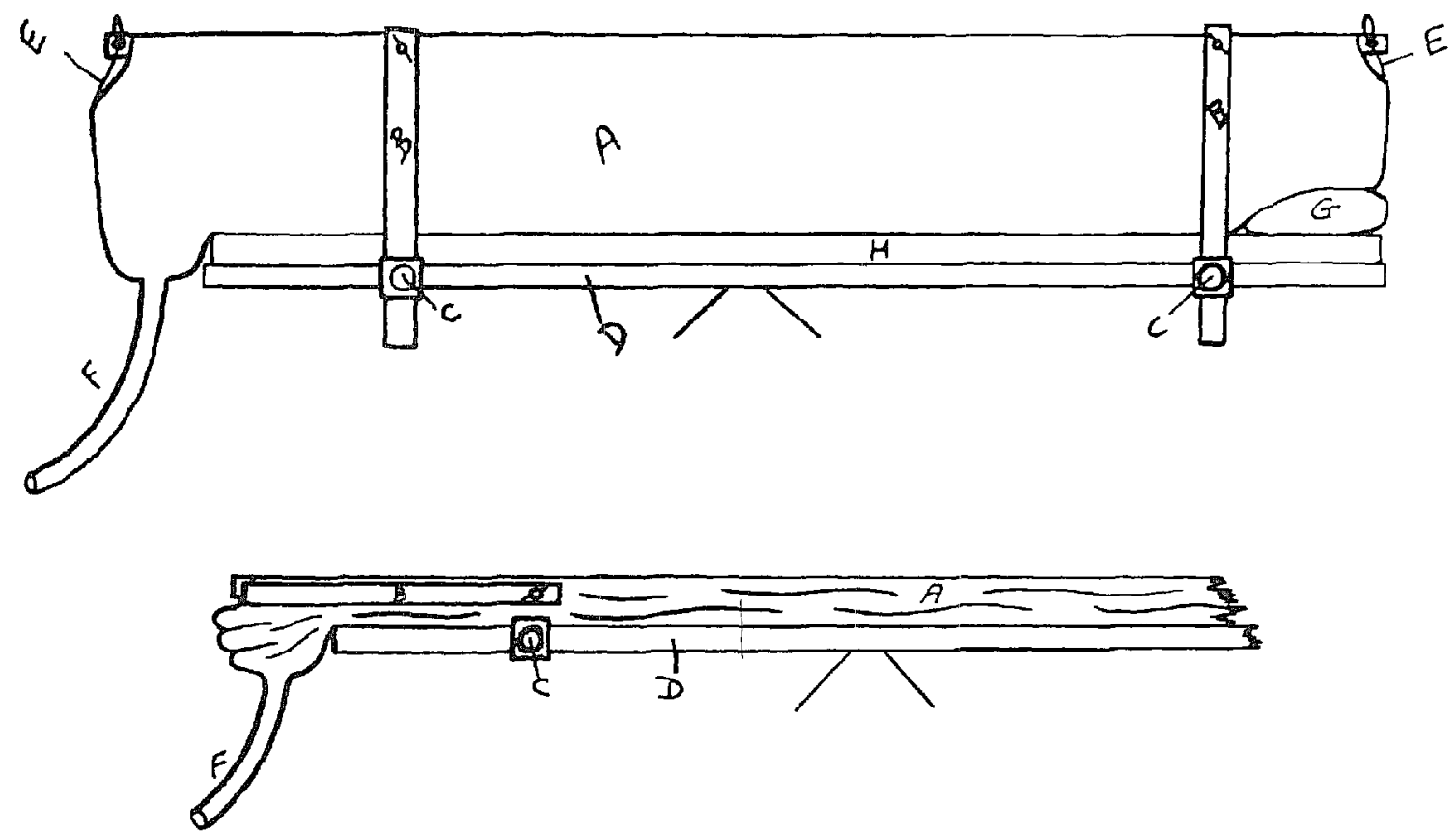

Figure 2. Top: tub erect. Bottom: tub collapsed. A, side of rubber tub; B, vertical support inserted in screw-clamp; $\mathrm{C}$, screw-clamp attached to side rail of table; $\mathrm{D}$, side rail of table; $E$, sash cord drawstring pulled taut and tied to raise end of tub; $F$, drain hose ( 1 inch diameter) of rubber incorporated in end of table; $G$, pillow under head end of tub to support head of patient; H, O.R. table mattress. 
Since the temperature of the perfusate is $40.5^{\circ} \mathrm{C}$., this provides a temperature gradient of approximately $10^{\circ} \mathrm{C}$. Where the site of the operation prevents the use of this warming technique the patient's temperature is restored to normal following operation by the use of hot-water warming blankets.

By the above technique we have achieved a state in the patient favouring the uptake of the cytotoxic agent by the cancerous tissue while at the same time protecting normal tissues. This has been accomplished by having the perfused area at a high temperature and low $\mathrm{pH}$, while the remainder of the body is at a low temperature and a high $\mathrm{pH}$.

\section{SUMMARY}

The indications for employing hypothermia in cancer perfusion therapy have been reviewed and the technique for carrying out this procedure described. An inexpensive, readily constructed, collapsable rubber tub has been used for surface cooling and the specifications for construction described.

\section{RÉSUMÉ}

Récemment, des techniques de perfusion des régions cancéreuses de l'organisme à l'aide d'agents cytotoxiques ont été élaborées.

On a déjà démontré que d'une part, la quantité d'agent cytotoxique prise par les tissus cancéreux augmente proportionnellement à la température et d'une façon inversement proportionnelle au $\mathrm{pH}$, et que, d'autre part, un agent cytotoxique \$'échappant de la région perfusée produit moins d'effectšs secondaires indésirables, tel qu'hypofonctionnement de la moëlle osseuse, si le reste du corps est maintenu à une basse température et a un pH élevé.

Dans le but de réaliser ces conditions nous avons utilisé un appareil à circulation extra-corporelle pour la perfusion de la région cancéreuse. Le sang contenant l'agent cytotoxique est alors réchauffé à $42^{\circ} \mathrm{C}$. alors que le reste du corps est maintenu en hypothermie.

La technique anesthésique consiste en un blocage épidural à un niveau élevé ainsi qu'en une anesthésie générale au protoxyde d'azote-oxygène avec respiration controllée durant toute la durée de la perfusion.

Le but de l'épidurale est de facilitier l'hypothermie et d'inhiber l'innervation sympathique des surrénales, réduisant ainsi la décharge des catécholamines endogènes. Le but de la respiration controllée est d'entretenir une ålcalose respiratoire modérée.

Cette association d'un niveau sanguin peu élevé des catécholamines et d'une alcalose respiratoire modérée, suivant les experiences de Galindo, protège le cœur de la fibrillation ventriculaire. Pour initier l'hypothermie, on a employé le refroidissement en surface à l'aide d'un bain caoutchouté, flexible, peu coûteux et facile a frabriquer.

Des photos avec tous les renseignements nécessaires sont incluses dans l'article. 


\section{REFERENCES}

1. Berged, F. Cancer Chemotherapy Rep. 10:37 (1960).

2. Rochlin, D. B.; Thaxter, T. H.; Dickerson, A. G.; \& Shiner, J. The Effect of Tissue Temperature on the Binding of Alkylating Agents in the Isolation Perfusion Treatment of Cancer. Surg., Gynec. Obst. 113: 555 (1961).

3. Shingleton, W. \& Pafker, R. T. Abdominal Perfusion with Hypothermia and Hyperthermia. Cancer Chemotherapy Rep. 10: 35 (1960).

4. Buckner, D. M.; Busch, J.; Economou, S. G. An Experimental Study of Influences on the Escape of Perfusate during Perfusion for Cancer. Cancer Chemotherapy Rep. 11: 41 (April, 1961).

5. Lee, J. M.; Lesage, A. M.; Sealy, W. C., Young, W. G., Jr. Differential Perfusion Hypothermia: Its Use in Selective Bone Marrow Protection during Administration of Nitrogen Mustard. J.A.M.A. 179: 435 (1962).

6. Bromage, P. R. Continuous Lumbar Epidural Analgesia for Obstetrics. Canad. M.A.J. 85: 1136 (1961).

7. Galindo, Anibal H. Personal Communication.

8. Goldeerg, Mark A.; Barlow, Charles F.; \& Roth, Lloyd J. The Effects of $\mathrm{CO}_{2}$ on the Entry and Accumulation of Drugs in the Central Nervous System. J. Pharmacol. \& Exper. Therap. 131: 308 (1961).

9. Rall, Dayid P.; Stobenau, James R.; \& Zubrod, Charles G. Distribution of Drugs between Blood and Cerebrospinal Fluid. J. Pharmacol. \& Exper. Therap. 125: 185 (1959).

10. Radford, E. P., Jr.; Ferris, B. G.; \& Kriete, B. C. Clinical Use of a Nomogram to Estimate Proper Ventilation during Artificial Respiration. New Engl. J. Med. 251: 878 (1954). $\forall$

11. Massa, D. J.; Lundy, J. S.; Faulconer, Albert, Jr.; \& Ridley, R. W. A Plastic Needle Procedure. Staff Meeting Mayo Clinic 25: 413 (1950). 